\title{
1. The sources of monopoly power in the history of economic thought ${ }^{1}$
}

\subsection{INTRODUCTION}

When was the notion of market power defined? And how has it been explained in the history of economic thought? In this chapter, we distinguish four different fields of enquiry in which to seek a history of ideas on the causes of market power. The first concerns the history of the formal models of profit maximisation in imperfectly competitive markets; the second, competition policies in a historical perspective; the third, the theory of competition in economic thought; and the fourth, the development of the notion of entry barriers. This chapter is of a historiographical character and places this book within the existing panorama of the secondary literature. Moreover, it has been written in the conviction that in the study of economic thought one cannot restrict oneself to simply narrating a history, one must also have some very good reasons for doing so.

\subsection{FIELDS OF ENQUIRY}

The four possible fields of enquiry in which to seek the origins of the notion of monopoly power are to be found within the pre-history and history of industrial economics and competition policies. This is true insofar as market power is the characteristic feature of all imperfectly competitive markets, so the natural place to look to follow its historical

1 A previous version of this chapter was presented to the Conference 'Histoire des théories en économie publique' (Paris, 10-12 December 2008), in a seminar at the Dipartimento di scienze economiche e matematico-statistiche, University of Salento (Lecce, 14 January 2009), at the 73rd Annual Meeting of JSHET, Keio Gijuku University (Tokyo, 30-31 May 2009) and at the 36th Annual Conference of HES, University of Colorado at Denver (Denver, 26-29 June 2009). It was also published as a working paper (Mosca 2009); some ideas presented here are also included in Mosca (2008) and Mosca (2016a). 
development is in these fields. Nevertheless, as we shall see, also the historiography of the theory of competition will provide various ideas for a history of the sources of market power.

\subsubsection{The History of Formal Models}

The first field of enquiry concerns the attempts to calculate equilibrium prices and quantities in imperfectly competitive markets. The history of these attempts has been reconstructed by many scholars, ${ }^{2}$ who all agree on the fact that it began with the work of Cournot (1838), followed by Dupuit (1844), Bertrand (1883), Launhardt (1885), Auspitz and Lieben (1889), Edgeworth (1897), Bowley (1924), Hotelling (1929), Chamberlin (1933) and J. Robinson (1933). ${ }^{3}$ These formal models do not consider entry of new firms, and do not pay much attention to the causes of market power, often taking them as given. ${ }^{4}$ These are the reasons why the historiography that focused on profit maximisation models in imperfectly competitive markets has little to say about the causes of monopoly power in economic thought.

\subsubsection{The History of Competition Policies}

The second field of enquiry concerns the history of the theory behind the two main competition policies, namely antitrust policy and regulation. ${ }^{5}$

2 See, among others, Schumpeter (1954), West (1978), Stigler (1982), Niehans (1990), Ekelund and Hébert (1999), Puu (2002, pp. 1-5).

3 The reason I stop at the 1930s is explained further on in section 1.3.

4 Modigliani for example writes that the impossibility of entry is frequently at least implicitly assumed in the analysis of oligopoly, following the venerable example of Cournot, with his owners of mineral wells' (1958, p. 216). And according to Ekelund and Hébert, among all the 'pioneers' they cite, 'Dupuit alone examined in detail the sources of monopoly' (1999, p. 19, my italics); I have already mentioned this in my Introduction. Clearly, in the models of monopolistic and imperfect competition the cause of market power is explicitly indicated in product differentiation (Hicks 1935). See section 1.2.4.2.

5 'The main instruments of competition policy are: antitrust policy, the policy for the efficiency of financial markets, regulation, the production of public services, the policy for innovations and patents' (Grillo and Silva 1989, p. 501); here we restrict ourselves to considering the two main ones. Unless stated otherwise, the translations of quotations are my own. 


\subsubsection{The history of antitrust}

Since the specific purpose of the firms at which antitrust legislation is directed is that of obtaining and enhancing their own market power, it would be reasonable to expect to find the history of the discovery of the causes of monopoly power by analysing the theories that have inspired antitrust legislation over the years. The developmental history of antitrust policy has been the subject of a great many studies: some of them affirm that in the first decades of its activities antitrust was moved more by political and social considerations than by economic ones; 6 others argue the presence of a strong influence of economic theory right from its very beginnings. ${ }^{7}$ This latter position ${ }^{8}$ would involve the possibility of reconstructing the development of the ideas on the causes of market power by means of a comprehensive review of the theories behind the antitrust legislation; however, even if one were to accept the most extreme version of this position, we still wouldn't find the history we are looking for, for various reasons.

The first of these is that antitrust does not consider the existence of market power illegal per se, ${ }^{9}$ but restricts its interest to those cases in which firms, to obtain it, adopt anticompetitive practices. ${ }^{10}$ So, we in this historiography cannot find a general interest in the causes of monopoly

6 Peritz (1990) cit. in Giocoli (2009). Stigler (1982) was still sceptical about the influence of the economists on antitrust policy.

7 See, for example, Hovenkamp (1989b), Kovacic (1992) and Meese (2003).

8 In the words of Hovenkamp, 'Antitrust policy has been forged by economic ideology since its inception' ([1989b] 1991, p. 136); and 'The antitrust laws are [...] eternally wedded to prevailing economic doctrine' (p. 157).

9 However, there are practices considered violations per se that it held necessarily procure market power (and in fact do not require an enquiry into their existence); e.g. antitrust has almost always considered price agreements illegal per se, holding them to be clearly a cause of market power. For EU competition policy, the exercise of market power is, in principle, an abuse of a dominant position, although cases where this rule has been applied are rare. I thank S. Martin for this suggestion.

10 These practices consist of: collusive behaviour, mergers and takeovers, monopolisation (in the United States) or abuse of dominant position (in Europe). Within the latter, practices excluding rivals take on especial significance. 
power, ${ }^{11}$ because its interest is limited merely to those kinds of behaviour $^{12}$ that generate market power by restraining competition. ${ }^{13}$

The second reason is the following: if in the evaluation of illegal behaviour, the rule of reason approach is adopted, ${ }^{14}$ judgement is based on the principle of reasonableness, according to which it is not enough that an action, to be condemned, restrains competition, it also has to restrain it unreasonably. By adopting this approach, therefore, an anticompetitive practice aiming at the acquisition of market power that, however, restrains competition 'reasonably', would not be condemned. In this context, the main causes of monopoly power for antitrust change according to whether such power is judged reasonable, which further explains why the historiography of ideas behind antitrust legislation cannot contain a general analysis of the causes of monopoly power. ${ }^{15}$

The third reason is that the only economists who are believed to have influenced antitrust at its beginnings are Americans; ${ }^{16}$ this cuts out all the economic thought which, starting from the latter part of the nineteenth century in the rest of the world, focused on the development of a good deal of thinking on antitrust policies.

11 For example, market power that all firms inevitably enjoy through the absence of perfect competition in actual markets is obviously not the object of antitrust enquiry, nor is that achieved due to merit, nor that deriving from natural monopolies.

12 The attention paid by antitrust to market share is explicable in that it is considered as evidence of behaviour that could have illegally generated market power.

13 And in a recent approach this restraint also has to be 'detrimental' (Motta 2004, p. xvii). A criticism of this approach is found in Grillo (2006). See also the approach put forward by Etro (2006).

14 In enacting antitrust legislation the rule of reason has been widely adopted. See Kovacic and Shapiro (2000). The various meanings attributed to the rule of reason in the history of antitrust are examined in Grillo (2006).

15 On the relationship between the character of the violations and market power from a different perspective, but one compatible with ours, see Krattenmaker, Lande and Salop (1987, p. 242).

16 See the examination of the literature in Giocoli (2009). The author formulates convincing hypotheses on the history of antitrust in Europe, which is beyond our temporal horizon in that, as is well known, it has much more recent origins (the Treaty of Rome was signed in 1957). For the debates on the issue of monopoly power in the case of predatory pricing in the history of American antitrust see Giocoli (2014). 


\subsubsection{Industrial regulation}

Within this second field of enquiry we also need to use historical perspective for the theory of regulation policies. Nevertheless, since policies of this kind aim to intervene in industries characterised by natural monopoly, they are linked to just one of the causes of monopoly power, namely economies of scale, which are included in our reconstruction, but by no means make up the whole of it. ${ }^{17}$

\subsubsection{The Historiography on Competition}

The third research path turns to the literature specifically devoted to the history of the notion of competition, with the idea of arriving at information indirectly on the non-legal sources of market power. ${ }^{18}$ This is not an easy thing to do, because the historiography on competition in general does not raise the problem of implications for ideas about monopoly power, and because the two notions are not always antithetical. Only if competition is characterised by perfect elasticity of the firm's demand curve, is it antithetical to market power: the competition thus defined necessarily implies absence of monopoly power. In this case, the list of the conditions associated with perfect competition provides us with all the information we need on the causes of market power: the latter in fact emerges exclusively if one or more of these conditions do not occur. ${ }^{19}$ Yet as we shall see, the notion of perfect competition was fully defined only in the 1930s. Before that, competition was treated as an activity, ${ }^{20}$ and to compete meant to undertake strategies precisely to obtain monopoly power; that is, to set prices so as to make positive profits: ${ }^{21}$ in this situation, there can clearly be no antithesis between competition and market power.

\footnotetext{
17 On the origins and history of the concept of natural monopoly see Mosca (2008).

18 In this work, we do not deal with legal protection from competition, because the recognition of this kind of entry barrier has never been problematic, being simply attributed to the government.

19 See Machovec (1995, pp. 179-181). Berta, Julien and Tricou (2012, pp. 1011) note that these conditions are not normalised in the literature.

20 As a result, the term was applied to any kind of market structure. See MacNulty (1967, p. 397), Backhouse (1990, pp. 59-63), Blaug (1997, p. 67; 2001a, p. 153; 2001b, p. 39), Bradley (2010).

21 Which is a very different thing from assuming given prices and zero economic profit as in the model of perfect competition (MacNulty 1967, p. 399; 1968, p. 656).
} 
On examining this literature to seek the causes of monopoly power we therefore have to be careful to distinguish between the two cases: whereas in the former the causes of market power coincide with the obstacles to perfect competition, in the latter the firm's behaviour in obtaining market power is in fact an expression of competition.

\subsubsection{Competition in the classicals}

We start with an examination of the literature on competition in the classicals with the aim of finding their views on the causes of monopoly power. Beyond the legal restraints, which as we have already said do not come within the scope of our present work, the uncovering of other sources of market power, such as limited knowledge, collusion, imperfect factor mobility and inelastic supply is down to Smith (1776). In addition, it is held that for Smith the number of rivals in a market was important for determining market power. ${ }^{22}$ It is stated that to Bailey (1825) we owe the interesting analyses of 'monopolies' with restricted entry and one or more sellers, as well as that of markets in which the producers have a cost advantage over the new entrants; he also highlighted the role of potential competition. ${ }^{23}$ Senior (1836) is cited for having worked on the impossibility of transferring capital from one use to another without incurring losses, and of the unavailability of information on profits; ${ }^{24}$ at the same time, it is thought that for Senior the number of firms was unimportant. ${ }^{25}$ J.S. Mill (1848) is remembered for having paid attention to consumers' 'custom'; 26 as far as the number of firms is concerned, the idea that "concentration will inevitably lead to some "contrivance to raise prices" or some form of "combination among dealers"' 27 is attributed to J.S. Mill, as well as to Smith. Cairnes (1874) is described as interested specifically in cases of monopoly power within his 'non-competing groups'.28

22 Stigler (1957, p. 2 and 1987, pp. 531-532) and Bradley (2010). By contrast, Blaug (1997) states that 'only once did Smith ever mention the number of rivals involved in competition' (p. 68).

23 Backhouse (1990, pp. 60-61).

24 Stigler (1957, p. 3 and 1987, p. 532).

25 Machovec (1995, p. 118).

26 Backhouse (1990, p. 66). Schumpeter ([1954] 1976, p. 546), Machovec (1995, p. 132). L.R.P. (1925, p. 378) recalls in general that 'much [...] of his treatise is devoted to showing its [of competition] limitations in practice'.

27 Bradley (2010).

28 Stigler (1957, pp. 3-4), L.R.P. (1925, p. 378), Backhouse (1990, p. 61). 
To sum up, and in the light of the previous distinction, we can state that the classicals had singled out a series of causes from which they believed monopoly power for firms could derive: some of them (agreements, limited knowledge due to the withholding of information) are to be considered strategies to compete, ${ }^{29}$ others (imperfect factor mobility, inelastic input supply, custom) were seen as real constraints on the competitive process. ${ }^{30}$ The latter were however seen as temporary, but to this we shall be returning (section 3.1). On the importance of the number of firms for competition, as we have seen, there was no agreement.

\subsubsection{Marginalist and neolassical competition}

We will now seek the sources of monopoly power in the literature on competition in marginalist and neoclassical thought. ${ }^{31}$ As we shall see, in that age the foundations were laid for the conception of competition as the market structure in which prices instantaneously converge to costs, without moreover abandoning the classical idea of competition as an activity, which we have just examined. ${ }^{32}$ This is the reason why most of the economists dealt with in this section are different from those included in section 1.2.1 (The History of Formal Models). This is not the case for Cournot (1838) who, as we know, paid no attention to the conditions of entry, yet in the literature on competition he is cited for one aspect that also interests us here: his theory establishes that if the firms are few, they have market power. ${ }^{33}$ Jevons (1871) is remembered for his 'law of indifference', ${ }^{34}$ which characterises perfect markets. ${ }^{35}$ Edgeworth's Mathematical Psychics (1881) is considered the first work to list certain conditions without which agents cannot compete or, to use his term,

29 Hart (2001, p. 3) recalls for example that for the classicals 'technological change was the natural result of economic competition'.

30 We do not share the idea that in the classicals' thinking the non-legal obstacles to competition were entirely absent. For example, Hovenkamp is being reductive when he sees in the classicals 'the absence of any notion of barrier to entry' ([1989b] 1991, p. 148).

31 For the distinction between these two categories see our Introduction.

32 We will come back to this later in this chapter, as well as in Chapter 2.

33 Stigler (1957, pp. 5-6 and 1987, p. 533); Bradley (2010, pp. 242-243); Dos Santos Ferreira (2012, pp. 207-208). We should also remember that Cournot is held not to have really believed that competition existed in most real markets.

34 Backhouse (1990, pp. 66-67); according to this law, in a market there cannot be two different prices for the same good.

35 Stigler (1957, p. 6). A perfect market for Jevons requires perfect information and 'perfectly free' competition, not better defined. On Jevons' view of perfect competition see also Dos Santos Ferreira (2012, p. 212). 
'recontract': free communication, ${ }^{36}$ divisibility of goods, ${ }^{37}$ a large number of sellers. ${ }^{38}$ As we know, Bertrand (1883) is known for his theory of price competition, ${ }^{39}$ which makes the number of firms in the market irrelevant. Marshall (1890a, 1890b) confidently proposes that the 'race' of competition can take place, on the condition that there is sufficient knowledge and absence of agreements. ${ }^{40}$ It has also been argued that Marshall's conception of competition left no room for long-run concerns. ${ }^{41}$ Hadley (1896) is cited for the role played by custom, ${ }^{42}$ as in J.S. Mill, but above all for finding natural monopolies. ${ }^{43}$ J.B. Clark (1887, 1901, 1904) is remembered for having held that firms operating in the market are capable of preventing entry, ${ }^{44}$ and even of eliminating potential competition. ${ }^{45} \mathrm{He}$ is also cited (J.B. Clark 1899) for having added two more conditions to those of Edgeworth: the instantaneous mobility of resources and the identification of competition with stationary equilibrium. ${ }^{46}$ Wicksell (1901) and Moore (1906) are mentioned for

Backhouse (1990, p. 77)

Stigler (1957, p. 7 and 1987, p. 534).

8 Backhouse (1990, p. 78), Dos Santos Ferreira (2012, pp. 209-210).

39 Backhouse (1990, p. 69).

40 Stigler (1957, p. 9). In general, it is held that Marshall was aware that perfect competition requires small firms and given prices, but that he didn't push his argument as far as that formulation (Peterson 1957, p. 72; Corley 1990, p. 84). In a marvellous passage, Schumpeter gives an explanation for this, writing that Marshall 'was bent on salvaging every bit of real life he could possibly leave in $[\ldots]$ he did not attempt to beat out the logic of competition to its thinnest leaf' ([1954] 1976, p. 974).

41 According to Chamberlin, for Marshall the phenomenon of the 'industries in which each firm is likely to be confined more or less to its own particular market' is exclusively 'short time' ([1933] 1956, pp. 69-70). Similarly, Sylos Labini ([1957] 1962, p. 12) notes that for Marshall the big industrial enterprises may not have monopoly power and cites him, 'the last years of the nineteenth century and the first years of this have shown that even in these cases competition has a much greater force'. Utton (2007, p. 113) recalls that, 'Marshall continually emphasized the fragile and conditional nature of $[\ldots]$ monopolies. They are perpetually under threat from the vigorous new entrant, the alternative source of supply and the substitute product or material'.

42 Morgan (1993, p. 573).

43 Morgan (1993, pp. 593-594).

44 Morgan (1993, pp. 586-587).

45 'Successful combinations, by fixing prices and production, could limit both real and potential competition' (Morgan 1993, p. 587).

46 Stigler (1957, p. 11). 
having provided new lists of necessary conditions for competition. ${ }^{47}$ Wicksell (1901) is also remembered for having traced the causes of monopoly in large overhead costs and joint supply, in price stability, and in location, ${ }^{48}$ while H.C. Adams (1918) is considered among those who believed firm size to be the cause of market power. ${ }^{49}$ Finally, the greatest effort to set down the conditions for perfect competition is down to Knight (1921b), ${ }^{50}$ and it should also be noted that he didn't believe in it. ${ }^{51}$ It was precisely Knight who prepared the way for the reaction in the 1930s against the theory of perfectly competitive markets, ${ }^{52}$ then initiated by Sraffa, and ironically it was Chamberlin ${ }^{53}$ and Robinson ${ }^{54}$ who definitively perfected this static notion. The "principle of excluded strategy' having prevailed, ${ }^{55}$ it is said that after this age every action undertaken to compete was considered proof of monopoly power. ${ }^{56} \mathrm{We}$ shall be returning to this statement (section 1.3.2).

47 For Wicksell, 'There must be a uniform product, firms must be small in size and there must be constant returns to scale' (Backhouse 1990, p. 70). Moore lists five conditions, but 'His first two items state the conditions of price uniformity and profit maximization. Conditions III, IV and V are stated in such a way as to create doubts about the distinction between premise and consequence' (Dennis 1977, p. 272); see also Stigler (1957, p. 9).

48 Backhouse (1990, pp. 70-71).

49 DiLorenzo and High (1988, p. 429).

50 Stigler (1957, p. 11) and Machovec (1995, pp. 163-164).

51 See Stigler (1957, p. 11), Dennis (1977, pp. 273-275).

52 'It was the meticulous discussion in this work that did most to drive home to economists generally the austere nature of the rigorously defined concept and so prepared the way for the widespread reaction against it in the 1930's' (Stigler 1957, p. 11); 'Knight highlighted the severely abstract character of perfect competition in such a way that led other theorists to hunt for more plausibly realistic models of market behaviour' (Dennis 1977, p. 270).

53 Peterson $(1957$, p. 76$)$.

54 Dennis (1977, pp. 270-271) writes, 'Chamberlin [and] Robinson had to specify more precisely what the model of perfect competition itself entailed, so that a proper contrast could be drawn with the newer models', and Machovec (1995, p. 181) states that 'the Chamberlin/Robinson model provided the capstone for the triumph of equilibrium theory'.

55 'The Principle of Excluded Strategy' is the colourful and predictive expression Schumpeter uses ([1954] 1976, p. 972) to indicate perfect competition.

56 Machovec (1995, p. 180): 'as the neoclassical conceptions of competition and monopoly began to take hold, nearly every traditional means of competing came to be interpreted as unlawful'. Blaug (1997, p. 68): 'every act of competition [...] was now taken as evidence of some degree of monopoly power, and hence a departure from perfect competition'. See also Blaug (2001b, p. 39). 
As can be seen, for the age examined here as well as for the classical age, we can divide the causes of market power into two categories: (i) those due to strategic behaviour (agreements, information withholding, product differentiation), and (ii) those owing to external factors (technology, indivisibility, inelastic input supply, custom), while the significance or otherwise of the number of firms remains controversial. ${ }^{57}$ We also point out that, as the definition of the conditions for perfect competition gradually becomes more rigorous, it is denied that those conditions can be realised. 58

In the historiography focused on the notion of competition there is therefore interesting material for a history of the causes of market power. Further on (section 3) we will look much more closely at the consequences these ideas have for our research. For the moment, however, we shall restrict ourselves to noticing, together with most of the relevant secondary literature, that in this period there were several concepts of competition, and they co-existed side by side.

\subsubsection{The History of the Notion of Entry Barriers}

The fourth field of inquiry concerns the literature dealing with the way industrial economists of the past have answered the question, 'Which factors generate situations in which firms have market power; that is, in which they are able to set their prices?'59 The findings of this literature overlap very little with those of the historiography focused on profitmaximisation models in non-competitive markets, as well as on antitrust

57 Dos Santos Ferreira (2012) makes a distinction between Cournot and Edgeworth on the one hand, for whom the size of firms matters, and Jevons, Walras and Bertrand on the other hand, who see price-taking behaviour as independent of size.

58 Peterson (1957, p. 65) for example cites J.B. Clark (1899), 'a static state [...] is imaginary'. Certainly, this is true for the short run; as Morgan (1993) notes: 'imperfections in the market delay the effects of the working of the static laws' (p. 589, my italics).

59 For those who argue that monopoly power is generated exclusively by legal protection this question makes no sense. For example, certain exponents of the Chicago School state that 'firms cannot in general obtain or enhance monopoly power by unilateral action' (Posner 1979, p. 928). The Neo-Austrian School, basing itself on different methodological foundations, argues that 'Monopoly power [...] is always associated with legal, third-party restraints on either business rivalry or cooperation, not with strictly free-market activity' (Armentano 1999, p. 18). 
and on competition. We shall examine three periods, beginning with the most recent.

\subsubsection{From Bain to the present day}

Starting from the contribution of Joe Bain (1956), who studied at Harvard, industrial economics provided the following answer to our question: 'The causes of firms' market power are entry barriers'. In other words, the notion of entry barriers was used to explain the existence of monopoly power. So, we found the category our research was looking for in economic theory: entry barriers explain the presence of market power. We still have to ask ourselves if the history of this category had already been written. In fact, a history focused on the specific subject of the notion of entry barriers already exists, ${ }^{60}$ and to put it briefly, is the following:

Everything starts from Bain, who found entry barriers in economies of scale, product differentiation, and the absolute cost advantages of established firms. It should be noted that for Bain entry barriers allow incumbents to 'persistently raise their prices above a competitive level without attracting new firms to enter the industry' (Bain 1956, p. 3). So for Bain, profits above the normal level were a sign of the existence of entry barriers. ${ }^{61}$ For our own research, it is important to emphasise that independently of Bain, and in the same period, Sylos Labini (1957) studied the relationship between the number of firms and market power, also using the concept of entry barriers. ${ }^{62}$ Stigler (1968), from Chicago, attacking Bain's definition, defined entry barriers as a cost advantage of the firm already in the industry compared to those seeking to enter, thus detaching them from above-normal profits. With the two different definitions of Bain and Stigler, a controversy $\operatorname{arose}^{63}$ on the issue of which concrete situations act as entry barriers. ${ }^{64}$

60 On entry barriers in the history of economic thought starting from Bain there are the works of Keppler (2008) and Rosado Cubero (2008). However, the main information set down here can be drawn from textbooks of industrial economics.

61 In this context, it is worth remembering the title of an article of his, 'The Profit Rate as Measure of Monopoly Power' (Bain 1941).

62 Sylos Labini ([1957] 1962, pp. 54-55) also uses the term 'barriers', for example: 'In concentrated oligopoly, technology creates external barriers between each group of firms and its potential competitors'.

63 See for example McAfee et al. (2004), Carlton (2004), Schmalensee (2004).

64 As well as on the usefulness of the concept. Some exponents of the Chicago School wholly rejected the concept of entry barrier, e.g. Bork (1978, 
From Salop (1979) onwards, non-legal entry barriers were classified as 'innocent' and 'strategic', the former of a structural type, and hence exogenous, the latter activated by the incumbent, and hence endogenous. ${ }^{65}$ Basing itself on this theoretical categorisation, industrial economics first defined the causes of market power according to the structure-conduct-performance approach, ${ }^{66}$ and then, starting from the 1980 s, according to the 'new industrial economics'. For the former, monopoly power is a function of the degree of concentration of an industry, ${ }^{67}$ and depends on the existence of exogenous entry barriers. ${ }^{68}$ For the latter, it is not a function of the concentration, ${ }^{69}$ and depends on both exogenous and endogenous entry barriers. Notice that the latter are strategic barriers, so they imply competitive behaviour by the firm, akin to the activities to compete found by the classicals and those marginalists of whom we spoke in the section on competition. ${ }^{70}$

Ch. 16), Demsetz (1982) and Posner (1979, p. 929); the latter calls entry barriers 'colourful characterizations'. Even more critical were the representatives of the Neo-Austrian School, for whom 'most of these alleged barriers have proven to be economies and efficiencies that leading firms have earned in the market-place' (Armentano 1999, p. 13).

65 See also Shepherd (1995, p. 303): 'I have assembled [...] some 14 sources of entry barriers which the literature has identified. They derive both from "exogenous" causes (that is, basic conditions such as technology) and "endogenous" conditions (that is, voluntary actions taken by the incumbent firms so as to make entry harder)'.

66 Some (for example Shepherd 2007, p. 209) hold that we owe this approach to Edward Mason, and thus to an age prior to the one under consideration in this section; we shall deal with Mason in the next section 1.2.4.2.

67 The degree of concentration provides indications on size (of market share) of firms present in an industry. 'An industry is concentrated if a small number of firms controls a large part of the economic activity of the entire sector' (Grillo and Silva 1989, p. 250).

68 The Chicago School opposed this approach, in particular Demsetz, Posner and Friedman, for whom the greater size of firms is a sign of greater efficiency, not market power (Martin 2007, pp. 39-43). The same position was taken by the Neo-Austrian School, for which 'a firm's market share is not its market power, but a reflection of its overall efficiency' (Armentano 1999, p. 18).

69 Hence for this approach the number and size of firms are not necessarily correlated to market power.

70 The similarity of these two conceptions is examined in Mosca (2016a). 


\subsubsection{From the birth of industrial organisation to the 1950s}

All this is widely known, but less well known is the way in which monopoly power was explained before the introduction of the category of entry barrier. In this section, we examine the period from the 1930s to Bain (1956). Although there is a large historiography on this period, ${ }^{71}$ it does not focus on the specific subject of the sources of market power, being devoted to tracing the birthplaces of industrial economics. Among them we cite only the three that seem to us the most significant: one is in the United Kingdom with J. Robinson (1933) and Lerner (1934), the other two are in the United States, the first at Harvard with E. Chamberlin (1933) and E.S. Mason (1939), the second at Chicago with H. Simons (1934). The interrelationships between the protagonists of these three groups over the two decades would deserve an entire study. Here, however, we just try to extrapolate the answers they provided to the questions that interest us; that is, 'What are the impediments to entry?' 'Do incumbents have monopoly power?'. We recall that in this period the latter was usually represented by a downward sloping demand curve for the firm. ${ }^{72}$

To begin with we can state that the controversies between these three schools do not seem to be about the specific subject of obstacles to entry. It is well known that the models of J. Robinson (1933) and Chamberlin (1933) are characterised by product differentiation; and it is likewise well known that this impediment to entry has both exogenous and endogenous features. ${ }^{73}$ On the basis of this theory, Chamberlin (1937) adopts a

71 Grillo and Silva (1989, pp. 28-29), Corley (1990), Martin (2007, pp. 2729), De Jong and Shepherd (2007) and the literature cited there. Bain (1948), Galbraith (1948), Keppler (1994a) and Marcuzzo (2003) are focused specifically on the decades examined in this section.

72 It seems to us that the representation of market power through a downward sloping demand curve is already contained in the following words of Sraffa (1926, p. 543): 'This necessity of reducing prices in order to sell a larger quantity of one's own product is only an aspect of the usual descending demand curve, with the difference that instead of concerning the whole of a commodity, whatever its origin, it relates only to the goods produced by a particular firm'. Chamberlin (1933), Robinson (1933), and Lerner (1934) use downward sloping demand curves for the individual firm. Mason (1939) rejects the analytical tools, including this representation, on the basis of them being empirically inapplicable.

73 Shepherd (1991) includes in the list of the factors that produce exogenous entry barriers 'Product differentiation (occurring naturally among products)' (p. 53) and in the one for endogenous entry barriers the 'Selling expenses, including advertising (to increase the degree of product differentiation)' (p. 54). 
complex position on free entry, ${ }^{74}$ while J. Robinson ${ }^{75}$ provides other examples of limitations to entry, both endogenous ${ }^{76}$ and exogenous. ${ }^{77}$ And while it is true that Mason focuses on technological factors, ${ }^{78}$ it is only because he believes that these and no others can be found empirically. ${ }^{79}$ On the other hand, Simons states that firm size is determined by exogenous factors, such as economies of scale, as well as by endogenous factors. ${ }^{80}$ It is not surprising therefore, that Bain in 1956 considered it obvious that before him economies of scale had been recognised by everyone, irrespective of the school they belonged to, as a deterrent to entry. ${ }^{81}$

As for the relationship between obstacles to entry and monopoly power, J. Robinson and Chamberlin both agree that a firm's demand curve can be perfectly elastic also in the presence of obstacles to entry, ${ }^{82}$

74 He states in fact that, "With respect to the particular product produced by any individual firm under monopolistic competition, there can be no 'freedom of entry' whatever [...] [but] there can be freedom of entry only in the sense of a freedom to produce substitutes; and in this sense freedom of entry is universal, since substitutes are entirely a matter of degree' (Chamberlin 1937, p. 567).

75 In her famous book, she does not go beyond the observation that 'the problem of the conditions influencing the entry of new firms [...] presents an interesting and largely unexplored field of inquiry' (Robinson [1933] 1969, p. 92, fn. 1), and she does deal with it in Robinson (1934).

76 She writes, 'the existing firms may be so strong that they are able to fend off fresh competition by the threat of a price war. They may even resort to violence to prevent fresh rivals from appearing on the scene' (Robinson 1934, p. 107).

77 For Robinson, entry is difficult in those industries 'which require unusual personal ability or special qualifications, such as power to command a large amount of capital for the initial investment' (Robinson 1934, p. 107).

78 Which he calls 'market control' (Mason 1939, pp. 61-62). See also Martin (2007, p. 37).

79 He writes, 'The objection is not that monopoly theory is incompatible with an analysis that takes [other] considerations into account but that its constructions are irrelevant to the real problems' (Mason 1939, p. 64). Bain also confirms this ([1948] 1953, p. 183).

80 Martin (2007, p. 32) argues that if on the one hand at Harvard it was believed that economic forces also influenced market structure, at Chicago up until the 1950s the role of technology was recognised as determining firm size (p. 38).

${ }^{81} \mathrm{He}$ also points out that, whereas judgement on large firms due to these economies in the UK was positive, the USA (Chicago included) was against concentration (Bain 1956, pp. 59-61).

82 The subject is barely mentioned in J. Robinson ([1933] 1937, p. 566): 'The case of a small number of firms selling in a perfect market raises some 
whereas they disagree on the importance of the number of firms in determining profit levels. ${ }^{83}$ Lerner (1934) criticises the idea that the degree of monopoly is based on the number and relative size of sellers; for him, market power exclusively depends on the availability of substitutes (which is reflected in the elasticity of the firm's demand). ${ }^{84}$ And, however ironic it may seem, Mason, the founder of the structure-conductperformance approach, shows that 'Data on numbers [...] tell us little regarding price and production policies' (1939, p. 64), whereas Simons (1936), the father of the Chicago School, attributes fundamental importance to firm size in the generation of market power (Martin 2007, p. 33).

These groundbreaking contributions published in the first half of the 1930s gave rise to a number of writings by scholars such as Kalecki (1938), Hall and Hitch (1939), Harrod (1939), J.M. Clark (1940), Schumpeter (1942), Rothschild (1942), Kaldor (1943), Andrews (1949), Papandreu (1949), and many others. To sum up, and reporting at the same time the situation described by Scitovsky in 1950, all of them recognise the existence of both exogenous and endogenous impediments to entry; 85 nevertheless, not all believe that they generate monopoly power.

Can it be argued that this state of affairs was simply due to the fact that the problem of the relation between free entry and market power had not been fully focused on? This is what the three innovators in the theory of oligopoly think, when they complain about the confusion reigning in the literature on conditions of entry before they appeared on the scene. ${ }^{86}$

difficulties, which are not here discussed'. By contrast, Robinson (1934, pp. 104111) and Chamberlin (1937, p. 566) state that the impediments to entry are entirely compatible with perfect competition, on condition that the demand curve for the firm is perfectly elastic. See Dos Santos Ferreira (2012, p. 209), 'the indefinitely raising elasticity of the supplied good to rival goods in other markets [...] is completely independent of market shares being small: even a monopolist is threatened by the existence of close substitutes to his output'.

83 See J. Robinson (1934, pp. 112-120) and Chamberlin's reply (1937, pp. 566-568 and p. 569, fn. 1).

84 According to Elzinga and Mills (2011, p. 558) the Lerner index is 'appropriate for assessing monopoly power of a firm [...] in homogeneous - or differentiated - product oligopolies, with or without free entry, and in homogeneous-product markets with a dominant firm'.

85 It is worth remembering that, before Bain, Scitovsky (1950) showed a specific interest in the sources of market power, and in particular on the role of ignorance as entry barrier.

86 We are obviously referring to Bain, Sylos Labini and Modigliani. Bain (1956, p. vi) illustrates how on the subject of 'condition of entry' received theory 
Martin's thesis (2007) nonetheless seems to us more convincing; according to this, the real opposition between schools of industrial economics only began in the $1960 \mathrm{~s},{ }^{87}$ after the attacks of the second Chicago School $^{88}$ (which, again according to Martin, the game theory approach finally proved wrong).

\subsubsection{Before the 1930s}

If from the historiography on industrial economics indirect references to the causes of market power can be drawn, we cannot avail ourselves of most of it for the years prior to the 1930s, which is considered the pre-history of this discipline. But since it is obvious that the ideas of the 1930s did not come from nowhere, we found some interesting references in those few works that go further back. ${ }^{89}$ Despite the great dissatisfaction often expressed about the state of the ideas formulated up until the 1930 s on the subject of the causes of monopoly power, ${ }^{90}$ we have drawn up a list of those earlier economic theorists who made contributions on

was 'in extremely rudimentary form'. Also, Sylos Labini ([1957] 1962, p. 9) writes that 'the analysis of the relationship between the process of concentration and market form is in a completely unsatisfactory state'; he also explains that, concerning 'the market power of very large industrial concerns [...] apart from the rather elementary observations of Smith and Marx, we are still in need of a really satisfactory theoretical analysis' (p. 11). And Modigliani (1958, p. 216) notes that 'little systematic attention [had] been paid [...] to the role of entry, that is, to the behaviour of potential competitors'. However, Modigliani alludes to a previous literature, though without specifying which, writing that the entry barriers that "Bain labels "absolute cost advantages" [...] have already been extensively analysed and understood in the received body of theory' and that the barrier 'resulting from the inability of potential competitors to produce a commodity that is a perfect substitute for the product of existing firms - is again one that has received considerable attention in the past' (Modigliani 1958, p. 231). It will be remembered that the literature following on from the 1950s has always pointed to this period as the origin for the thinking on the causes of market power.

87 This seems to us convincing despite the undeniable divergences between imperfect competition and monopolistic competition of which White (1936) speaks.

88 We are referring to the above cited diatribe on the definition of entry barriers and to the attack on the structure-conduct-performance approach by Stigler, Friedman, Coase, Posner, and others.

89 These works will be cited in the course of this section, the most important being those included in De Jong and Shepherd (2007).

90 For example, according to Nti and Shubik (1979) the study of entry in oligopoly theory was not dealt with before the brief treatment in Chamberlin (1933). 
precisely this subject. As we shall see, these contributions are seldom cited in the existing literature on the history of industrial organisation more generally, or in the literature on the various histories of certain aspects of economic thought that we have looked at in the preceding sections of this chapter.

We begin with the Scholastics of the Middle Ages, for whom the causes of monopoly were: 'engrossing, forestalling, regrating, illicit agreements, secret pacts, conspiracies, bidders' rings' ${ }^{91}$ Later, in the mid seventeenth century, the Dutchman Graswinkel argued that 'monopoly is not to be feared when there are many, but few' (1651, p. 158). ${ }^{92} \mathrm{~A}$ century further on, Cantillon (1755), standing in opposition to Graswinkel, stated that the number of competitors was not essential for rivalry to occur. ${ }^{93}$ Moving on to the classical economists of the eighteenth and nineteenth centuries, Smith (1776) is cited by this historiography, too, as by that on competition, for having identified situations where supply is persistently scarce compared to demand. ${ }^{94}$ Beyond these natural barriers, Smith advances other causes of market power, related to imperfect information, and to technologies (I. 7. 22) which he considers a temporary cause (I. 7. 21). He is often remembered also for having shown that a small number of entrepreneurs facilitate coalitions, ${ }^{95}$ and for having highlighted their propensity to come to agreements among themselves. ${ }^{96}$ Recently there has been discussion on how Smith's monopolists used strategies to enforce their legal barriers to entry. ${ }^{97}$ We have already recalled the role attributed by J.S. Mill (1848) to 'custom' as a restraint on competition; 98 he is also cited for "the baneful effect of small numbers on the vigour of competition' 99 and for his consideration of the influence

91 De Jong (2007a, p. 11, table 2.1).

92 De Jong (2007a, p. 22).

93 De Jong (2007a, p. 19).

94 'Some natural productions require such a singularity of soil and situation, that all the land in a great country [...] may not be sufficient to supply the effectual demand' Smith (1776, I. 7. 24) cit. in Mosca (2008, p. 322). On natural causes see also Smith (1776, I. 7. 20).

95 Smith (1776, I. 8. 12 and II. 5. 7) cit. in Sylos Labini ([1957] 1962, p. 8). On Adam Smith's views on collusion see also Levy and Peart (2008).

96 Smith (1776, I. 8. 13, but especially I. 10. 82 and I. 10. 85); he nevertheless believes such coalitions to be unstable. Cited in Stigler (1982, p. 1).

See Salvadori and Signorino (2014).

J.S. Mill (1848, II. 4. 3) cit. in Sylos Labini ([1957] 1962, p. 14).

99 Stigler (1982, p. 2) and Mosca (2008, pp. 333 and 337). 
of economies of scale. ${ }^{100}$ There is also Marx (1867), who is cited for the idea that the conspicuous "minimum capital necessary to start up production at sufficiently low costs $[\ldots]$ creates a "natural" hindrance to competition'. ${ }^{101}$ We also recall Marx's law of concentration of capital.

As far as marginalist thinking is concerned, the work of Dupuit (1854a; 1854b) is mentioned for having found some deterrents to entry in the transport sector; ${ }^{102} \mathrm{C}$. Menger (1871) for having considered monopoly an outcome of the limited size of markets; ${ }^{103}$ and H.C. Adams (1887) for the effects on market structure of increasing returns to scale. ${ }^{104}$ Marshall (1890) deserves a place to himself: on the specific subject of monopoly power, on the one hand his anthropomorphic theory of the growth of the firm, and the metaphor of the trees of the forest are regarded as unsuitable to deal with the phenomenon of large-scale industrial concentrations. ${ }^{105}$ On the other hand, he is also acknowledged for having identified the causes of the slope of a firm's demand curve, 106 and for his insights on the effect of advertising expenditure on economies of scale and on the significance of strategic barriers to entry. ${ }^{107} \mathrm{We}$ continue with Hadley (1896), who is considered in this literature for having focused on the importance of fixed costs ${ }^{108}$ and on the effects of

\footnotetext{
100 Stigler (1982, p. 3).

101 Marx (1867, I, XXIII, 2) cit. in Sylos Labini ([1957] 1962, p. 9).

102 In addition to the works cited in the introduction, see Ekelund and Hébert (1999, p. 323).

103 Niehans (1990, p. 279), De Jong (2007b, p. 35).

104 Hovenkamp (1989a, p. 123); Trebing (2007, pp. 173-174).

105 For example, Stigler (1950, p. 23), 'An anthropomorphic theory of the growth of the firm [...] scarcely fits our modern giants' and Sylos Labini ([1957] 1962, p. 169), 'According to Marshall [...] the trees of the forest must have been saplings once'.

106 Joan Robinson ([1933] 1969, p. 50) writes, citing Marshall, 'Its elasticity will depend upon many factors, of which the chief is the number of other firms selling the same commodity and the degree to which substitution is possible, from the point of view of buyers, between the output of other firms and the output of the firm in question. If there are few or no other firms producing closely similar commodities, the distribution of wealth among buyers, the conditions of supply of rival commodities, the conditions of supply of jointlydemanded commodities, and all the innumerable factors which affect the demand for any one commodity will influence the demand curve for the individual producer'. Sylos Labini ([1957] 1962, p. 51) comments on this that, according to Marshall, with the passing of time 'the demand schedule becomes more rigid'.

107 Utton (2007, pp. 113-114).

108 Hovenkamp (1989a, p. 125).
} 
the time necessary for new competitors to enter the market, ${ }^{109}$ and with Collier (1900), for having understood the strategic role of excess capacity. ${ }^{110}$ Ely (1900) is remembered for having grasped the monopolistic nature of trade-marks, ${ }^{111}$ and for stating that the existence of substitutes reduces market power ${ }^{112}$ and that economies of scale are a deterrent to entry. ${ }^{113}$ J.B. Clark $(1901 ; 1914)$ is spoken of for the role he attributes to predatory practices and, with the opposite effect on market power, to potential competition. ${ }^{114}$ Chamberlin then cites Taussig (1911), ${ }^{115}$ again for substitutes; and Fisher (1912), for the attention he paid 'to the idea of a separate market for each seller.' 116 In addition, he mentions Knight (1921a; 1921b) for the statement that 'every business is a partial monopoly' ${ }^{117}$ for the analysis of the effects of 'trade-marks, trade names, advertising slogans [...] reputations', ${ }^{118}$ differentiated products, ${ }^{119}$ and for having postulated that in competition, small firms must be more efficient than large ones. ${ }^{120}$ Chamberlin also deals with J.M. Clark (1923) for his emphasis on the number of firms, ${ }^{121}$ again on product differentiation; ${ }^{122}$ and on excess capacity. ${ }^{123}$ Finally, J. Robinson acknowledges Sraffa (1926) for saying that 'the entry of new firms into an imperfect market must necessarily be difficult', 124 while Chamberlin recalls the same article for the role of increasing returns; ${ }^{125}$ - Sraffa compares the firm that spends on advertising to a monopoly, thanks to the 'protection of its own barrier' (1926, p. 545). It is also worth noting here Chamberlin's citation of Hotelling (1929), both for the 'circles of customers [who]

109 Hovenkamp (1989a, p. 151).

110 Hovenkamp (1989a, p. 147).

111 Ely (1900, p. 43), cit. in Chamberlin ([1933] 1956, pp. 59-60).

112 Ely (1900, p. 35), cit. in Chamberlin ([1933] 1956, p. 66).

113 Hovenkamp (1989a, p. 147).

114 Stigler (1982, p. 4), Hovenkamp (1989a, pp. 147-148), Brown (2007, pp. 175-176).

115 Taussig (1911) cit. in Chamberlin ([1933] 1962, p. 66).

116 Fisher (1912, p. 323) cit. in Chamberlin ([1933] 1956, p. 69).

117 Knight (1921b), cit. in Chamberlin ([1933] 1956, p. 5).

118 Knight (1921b), cit. in Chamberlin ([1933] 1956, p. 60).

119 Knight (1921a, p. 332), cit. in Chamberlin ([1933] 1956, p. 70).

120 Knight (1921b), cit. in Chamberlin ([1933] 1956, p. 245).

121 J.M. Clark (1923, p. 417), cit. in Chamberlin ([1933] 1956, p. 49).

122 J.M. Clark (1923, p. 418), cit. in Chamberlin ([1933] 1956, p. 70).

123 J.M. Clark (1923, pp. 437-439), cit. in Chamberlin ([1933] 1956, p. 109); it is also cited in Hovenkamp (1989a, p. 148).

124 J. Robinson (1934, p. 105).

125 Chamberlin ([1933] 1962, p. 5). Sraffa's article of 1926 is cited by all the literature. 
make every entrepreneur a monopolist within a limited class and region', and for the statement that at the same time 'there is no monopoly which is not confined to a limited class or region'. ${ }^{126}$

As can be seen the list is not a short one and the causes of monopoly power are all there, exogenous and endogenous: strategies, economies of scale, absolute cost advantages, product differentiation, conditions of demand (elasticity and market size). There is also the idea that the number of firms may not affect market power or even that the entry barriers in the long run may not be effective at all. However, the literature examined above says little about the role the authors of the period before the 1930s played in respect to the uncovering of the causes of monopoly power. What is said amounts to no more than vague, random fragments, lacking a background of systematic study or interpretation.

\subsection{WHERE TO SEARCH?}

The historiography relative to the four fields we have analysed so far has never focused specifically on the subject of the causes of market power before the 1930s, thereby leaving a gap that we believe requires filling. In the light of the review we have just carried out of the literature on competition on the one hand and on the pre-history of industrial economics on the other, we may well ask ourselves at this point in which direction we should be concentrating our research in order to start writing a history of ideas on the sources of monopoly power.

\subsubsection{Why not Begin with the Classicals?}

The information we have gathered from the secondary literature tells us that the causes found by the classicals were in part endogenous, due to strategies carried out in order to compete, and in part exogenous, the fruit of constraints independent of the firms' intentions. These constraints, we have argued, were held to be mainly short run;127 in fact, the literature insistently recalls that in classical thinking restraints on competition had

\footnotetext{
126 Hotelling (1929, p. 44), cit. in Chamberlin ([1933], 1956, p. 6).

127 The term 'mainly' refers to the fact that, for example for Smith, certain factors of production could be scarce 'forever' (Smith 1776, I. 7. 24); see also Salvadori and Signorino (2014). J.S. Mill also believed that certain obstacles would last in the long run, for example: custom, the combinations (Schumpeter [1954] 1976, p. 546), and also natural monopolies (Mosca 2008).
} 
no importance in the long run. ${ }^{128}$ The monopoly power resulting from competitive strategies was hence considered by the classicals to be always present, but continuously threatened by competition, both actual and potential, except of course in the case of temporary exogenous obstacles. ${ }^{129}$ We also need to add that such a conception was valid for the classicals in theory as well as in reality, ${ }^{130}$ which means that competition was considered a widespread phenomenon, on condition the market was free from legal restraints. ${ }^{131}$ This optimism is further confirmed by the fact that in their writings the specific subject of monopoly takes up very little room. ${ }^{132}$ If the market power that the firms obtained through strategic behaviour did not worry the classicals because it was perpetually threatened, and if that due to exogenous obstacles did not go beyond the horizon of a short run that they judged unimportant, then it is clear that a detailed, coherent examination of the causes of monopoly power cannot be found in their thinking.

128 Hovenkamp (1989a): 'The analysis of classical political economists generally assumed that entry into markets was easy and could be accomplished very quickly' (p. 144, my italics). Machovec (1995): 'From a classical view [...] harm ensued only if institutions existed to inhibit the process of competition, independent of the presence of transitory monopoly profits due to $\mathrm{P}>\mathrm{MC}$ ' (p. 17, my italics). See also Giocoli (2017).

129 Hovenkamp (1989a, p. 149): 'Classicism's faith that potential competition would discipline incipient monopolists was based largely on its concepts of market entry barriers. Classical political economy recognized only government restrictions as barriers to competitive market entry'. It would be correct to add: in the long run.

130 Schumpeter ([1954] 1976, p. 545): "the "classics" [were] firmly convinced that the competitive case was the obvious thing'. This conviction holds true to the extent it is believed that the impediments were temporary or of small account.

131 Backhouse (1990, p. 60) notes that Smith on many occasions uses the term 'liberty' to indicate competition, and defines it precisely 'in terms of the absence of restraints'. It is interesting to note that Hovenkamp ([1989b] 1991, p. 148) indicates among the restrictions recognised by law also 'a privately created restriction on entry, either by a contract including the restricted person as a willing participant, or else by a combination directed at other people as target'.

132 Stigler (1987, p. 532): 'Demsetz has counted only one page in 90 devoted to monopoly in The Wealth of Nations and only one in 500 in Mill's Principles of Political Economy. Indeed, the world "monopoly" was usually restricted to grants by the sovereign'. 


\subsubsection{Why Begin with the Age of the Marginalists?}

The reasons we have just illustrated direct us towards the age of the marginalists, and this is what the secondary literature does on subjects akin to ours. ${ }^{133}$ But why this particular age?

We can find a general answer in the history of the sciences. In his obituary for Pareto, Pantaleoni (1923, p. 582) writes: 'The rate at which physical, biological, historical and economic science have been progressing in the last seventy years has precedents only in the times of the Renaissance'. In economic analysis in particular this has involved the attempt to use a truly scientific approach based on principles of marginal utility and productivity. Another answer can certainly be found in economic history. New phenomena such as trusts, cartels, mergers, the vertical integration of firms, public utilities, and the railways, ${ }^{134}$ raised new problems. Compared to the world of the classicals, the provisional character of the hindrances to competition no longer seemed to apply; ${ }^{135}$ in fact, the short run in some industries seemed to be very long, and in certain cases to enter a market turned out to be very difficult also in the absence of legal barriers. ${ }^{136}$ Faced with these new phenomena, economists tried to understand why in certain markets firms continued to be few, if they should be worried about their size, or if this was on the contrary an advantage, ${ }^{137}$ or whether one could count on their reciprocal rivalry. ${ }^{138}$ These questions gave rise to a quantity of studies on the subject of market power that was, as the review of the literature already provided has shown, without precedent. ${ }^{139}$

133 For example, De Jong and Shepherd write about industrial economics: 'There was major pioneering from the 1870s on' (2007, p. xxiii). Hovenkamp (1989a, p. 105), on dealing with the debates on the subject of antitrust, focuses on the 'waning years of the nineteenth century' and also Morgan (1993), dealing with competition, concentrates on this period.

134 These subjects are dealt with in Hovenkamp (1989a).

135 Hovenkamp (1989a, pp. $144 \mathrm{ff}$.) writes that in this age doubts began to be voiced about the classical idea that the savings of big firms were transferred on to consumers, and also that potential competition was always at work.

136 Hovenkamp (1989a, pp. 150-151). See also Giocoli (2017).

137 Hovenkamp (1989a, pp. 136-137) reports the various positions on the controversial hypothesis of 'ruinous competition'.

138 The latter is the idea that DiLorenzo and High (1988) attribute to the economists of the marginalist age.

139 Hart (2001) argues that the various positions of the economists reflected the popular division between supporters and opponents of the trusts due to the effect of these organisations on their business (p. 3). 
From a methodological perspective, how were these problems dealt with? It is well known that the years at the turn of the century were a kind of crossroads for a variety of different positions, in which the already bitter controversies between old classical thought and the new ideas of the historical school also had to face the marginalist paradigm that was making headway. The historiography on the subject of industrial economics shows that for a long time in the thought of this period, classical theory co-existed with historical analyses based on the examination of cases and on statistics, as it did with marginalist ideas that were slowly gaining ground. ${ }^{140}$ The historians of the theory of competition also point out this co-existence. ${ }^{141}$ So, we do not find a pure neoclassical theory in this period, ${ }^{142}$ but rather methodological contaminations that gave rise to a great wealth of ideas, as has already been shown through our account in the previous sections.

One significant aspect which helps to explain why it is worthwhile concentrating our analysis on the age of marginalism concerns the history of the analytical tools used by economists. We recall that Cournot, Dupuit, Ellet, Von Thünen and others ${ }^{143}$ had used mathematical tools, leaving their methods and their results to those who came after them: demand functions, cost curves, and equilibrium conditions were available at the end of the century for use in economic analysis. Some of the theoretical developments on the causes of monopoly power also came about through the logical necessity imposed by the analytical tools employed. ${ }^{144}$

This turn of the century preoccupation with the problem of monopoly and its causes came about for two different kinds of reason. The first,

140 Hovenkamp (1989a, p. 116): 'The earliest economic studies of the trust problem were dominated by broad, historically based inquiries', while Schumpeter notes, concerning the marginalists, that 'To a surprising extent they continued to look upon the competitive case as [in the preceding period, but] they complemented this vision by an analysis that was far superior to that of the "classics"” ([1954] 1976, p. 892).

141 'For three decades prior to 1920 a bifurcation period existed' (Machovec 1995, p. 97). The many different positions on the subject of competition present in this period in the US is the subject of Morgan (1993).

142 The construction of the neoclassical paradigm was a slow process, and the 'purification' of economic theory in the sense of reductionism occurred still more gradually. On reductionism in economics see Zamagni (2000).

143 On which see Niehans (1990) and Ekelund and Hébert (1999).

144 De Jong and Shepherd write that in this period in industrial economics 'basic concepts were invented as the new "neo-classical" microeconomic theory rapidly emerged' (2007, p. xix). 
linked to method, is that with the emergence of the notion of perfect competition, all strategic behaviour of firms became a sign of monopoly power, and as such was a cause for concern. The second, on the other hand, relates to the new economic situation in which market power, whether generated by strategies or obstacles, showed itself to be long lasting, which also created anxiety, although for other reasons. The difference between the two cases, however, should not be lost sight of: in the first case, the identification of monopoly power was due to a change only in the theoretical model, ${ }^{145}$ while in the second it was to be imputed to new circumstances in the real world.

\subsubsection{Why the Italian Marginalists?}

Schumpeter, referring to the high regard in which the economists of the marginalist age were held, remarks that: 'The most benevolent observer could not have paid any compliments to Italian economics in the early 1870s; the most malevolent observer could not have denied that it was second to none by 1914 '. ${ }^{146}$ Schumpeter's glowing tribute is certainly helpful as it reinforces our belief that the economic theory of the Italian marginalists is of great merit.

There are, however, other good reasons for studying this Italian thought, and they concern the specific subject of this work. The Italian marginalists wrote a great many studies on the subject of monopoly power, ${ }^{147}$ a problem that was not confined to the United States despite popular opinion to the contrary. ${ }^{148}$ Many Italian economists dealt with it, in part as a reflection of American and European realities, ${ }^{149}$ but also because of the industrial situation in Italy and the microeconomic policies followed (or indeed not followed) by Italian governments in the early decades of the twentieth century. It was the condition of Italian

145 This is Edgeworth's opinion, according to Machovec (1995, p. 288), 'Edgeworth's dissatisfaction with the concept of zero profit [...] was rooted in his realization that the new package of semantics and ideas attending the model of perfect competition were affecting how leading economists were reasoning about the market process'.

146 Schumpeter ([1954] 1976, p. 855).

147 They will be mentioned in Chapter 3, section 3.2.

148 Morgan (1993, p. 564, fn. 4) seems to support it, and adds that in both the UK and Germany the problem of competition between big firms was not raised, but De Jong (2007c, pp. 62-63), for example, recalls the German book Die Kartelle by Kleinwächter (1883). In this sense, also Gerber (1998).

149 See for example the case of Riccardo Dalla Volta, examined by Augello and Guidi (2009). 
industry that encouraged thinking on the subject of monopoly power, characterised by 'participations intersecting and in succession; holdings and groups, trade union agreements, also secret ones, interlocking directories, ${ }^{150}$ with at least some big linkers; interlocking relations between industry and the big banks; concentration of activities in the industrial triangle; districts'. ${ }^{151}$ The massive intervention by the government in the life of firms also provoked commentary from economists, thus revealing their idea on market power in the absence of this intervention. ${ }^{152}$

To these reasons taken from economic history, others can be added concerning the derivation of the ideas. The fact that the father of the theory of imperfect competition was Italian (Sraffa), as were two of the three founders of the new theory of oligopoly based on the notion of entry barriers (Sylos Labini and Modigliani), suggests that their ideas could have an Italian derivation. Also, the wholly Italian history of the working-out of U-shaped average cost curves, an instrument of fundamental importance for our subject, ${ }^{153}$ encourages us to continue exploring in this direction. Moreover, the role the Italian marginalists played in the definition of the notion of natural monopoly also offers good prospects for research on the subject of monopoly power in general. ${ }^{154}$

We conclude our line of argument by recalling, together with Modigliani, that the possibility of reading Italians in their own original language "is open only to the "happy few" (1958, p. 216); we therefore think it a duty and a privilege of Italians to carry out historical work on their primary sources.

\subsubsection{The economists considered}

In this book, we deal especially with four Italian marginalists: Vilfredo Pareto, Maffeo Pantaleoni, Antonio de Viti de Marco and Enrico Barone.

150 The sharing of administrators that allows big companies to form a network of connections.

151 Ciocca (2008, p. 159). Economic historians in general believe that the 'phenomenon of industrial concentration in the sectors of higher economies of scale emerges in Italy at the start of the twentieth century' (Amatori and Colli 1999, p. 117).

152 This issue will be examined in Chapter 5.

153 See Dooley (2001) and Keppler and Lallement (2006). They are important in particular for the structure-conduct-performance approach, since they allow the identification of various market structures.

154 Mosca (2008). 
Three of them were equal in age ${ }^{155}$ and three, but not the same three, died within a very short time of one another. ${ }^{156}$ Their biographers tell us of their deep personal ties: ${ }^{157}$ for example, Pantaleoni converted Pareto and Barone to economics; ${ }^{158}$ we know about the brotherly friendship between De Viti de Marco and Pantaleoni (Mosca 2016b); ${ }^{159}$ we have a wealth of correspondence between Pareto and Pantaleoni (De Rosa 1960), ${ }^{160}$ between the latter and Barone (Magnani and Bellanca 1991), between Pantaleoni and De Viti (Fusco 1983; Finoia 1993), and so on. And again, it is well known that three of them (De Viti de Marco, Pantaleoni and Pareto) gave rise together to a memorable series of the Giornale degli Economisti. ${ }^{161}$ It is precisely of our four economists that Einaudi (1934a) speaks in his preface to the First Principles of De Viti de Marco as of those who gave 'contributions to the pure theory of economics so important that they made [that] period [...] comparable with the most brilliant epochs in the history of our science' ([1928] 1936, p. 19). The point to emphasise here is the importance to our study of considering the group composed of these four figures as a single

155 Pantaleoni was born in 1857 , De Viti de Marco in 1858 and Barone in 1859. Pareto, ten years before, in 1848.

156 Pareto died in 1923, Barone in May 1924 and Pantaleoni in October of that year; De Viti de Marco lived for another two decades, dying in 1943.

157 We provide here only one of the many testimonies of their interrelationship in this letter from Pareto to Pantaleoni, 'All the theories I have set out are simply the germs of theories. Economists like Barone who have knowledge, culture and intelligence, should be the ones to develop these theories, and seek new truths' (Pareto 1960, vol. I, p. 455).

158 Pareto was an engineer, Barone was in the military forces (Magnani 2003, pp. 44-45, p. 72; Gentilucci 2006, p. 21).

159 De Viti de Marco and Pantaleoni had been fellow students since 1877 in the law faculty at the University of Rome, where they had studied the theories of Jevons (De Viti de Marco 1925a, p. 168) and Cairnes by themselves ('De Viti and I [...] challenged each other to solve problems based on Cairnes' [Letter to Loria of 1 March 1890, in Fiorot 1976, p. 477]).

160 The close ties between Pantaleoni and Pareto has also been written about by Chauvel and Fitoussi (1997).

161 Until 1897 (Magnani 2003, p. 211). Ugo Mazzola was also one of the leading lights of the Giornale degli Economisti. Barone took an active part in the project, as a reviewer (Gentilucci 2006, p. 28). Macchioro (1996, p. 10) speaks of a very violent Methodenstreit against all economic positivism led by the Giornale degli Economisti. For the role of the Giornale degli Economisti on Paretian thought see McLure (2007, Ch. 4). 
entity, ${ }^{162}$ since it was precisely their frequent intellectual contact and their reciprocal influence that affected the genesis and development of the ideas on market power.

It is by no means of secondary importance for the purposes of this study that for most of their lives they were all believers in free market and free trade and that all four were politically very active. They intervened in the political life of Italy, proposing reforms both in their works, as well as through direct participation: two were members of parliament (De Viti de Marco and Pantaleoni), and two tried to get elected (Barone and Pareto). Their period of militancy lasted from the mid-1880s to the arrival of fascism in $1923-24,{ }^{163}$ a time when, as we have noted already, issues concerning monopoly power dominated economic thinking; and since all four were free market and free trade economists, issues related to competition policies and market power feature prominently in their writings.

It is perhaps helpful to recall the reasons for their reputations, beginning with Pareto's everlasting fame due mainly to the concepts of Paretian optimum, of ordinal utility, to his law of income distribution, and in general to his contributions to Walras' theory of general economic equilibrium. ${ }^{164}$ Pantaleoni is considered the first economist to have applied the marginalist analysis to public finance, ${ }^{165}$ in 1883 . He was the author of a textbook on pure economics, which led him to be called 'the Italian Marshall' for the role it played in the Italian culture, ${ }^{166}$ and he wrote other very innovative works. ${ }^{167}$ The fame of De Viti de Marco is mainly due to the foundation of Scienza delle Finanze as a purely theoretical discipline, as well as his important contributions to the theory of banking, international economics and the history of economic

162 The subject of the Italian marginalists seen as a distinct intellectual tradition will be discussed in the conclusive chapter of this book. It was briefly dealt with in Mosca (2015b).

163 After that time the only survivor of the four, De Viti de Marco, remained silent for two decades, drafting his textbook on Scienza delle Finanze. These aspects will be dealt with in Chapter 5 .

164 Knight ([1921b] 1964, p. 6) considered Pareto 'the most prominent exponent of the mathematical method'.

165 Pantaleoni (1883) has priority over Emil Sax (1884); see Mosca (2010).

166 The quotation, which comes from the Italian economist Umberto Ricci, is reported in Groenewegen (1998, p. 45).

167 Pantaleoni's fame in his age is also attested by the following statement by Knight (1921b, 1964, p. 6): "Among "literary" pure theorists, Wicksteed, Schumpeter, and Pantaleoni stand out'. The historiography on Pantaleoni is examined in Bini (1995) and in Augello and Michelini (1997). 
thought. ${ }^{168}$ Finally, Barone is known mainly for his contributions to the theory of marginal productivity and the socialist calculation debate. ${ }^{169}$

The secondary literature also makes some references to them on subjects relevant to our enquiry. For example, Lombardini deals with Pareto and Pantaleoni's contributions to the theory of monopoly; 170 Schumpeter recalls Pareto's position on competition (as a precursor of the modern duopoly theory ${ }^{171}$ ) and, critically, on monopoly. ${ }^{172} \mathrm{He}$ also mentions Pantaleoni's study of industrial combinations ${ }^{173}$ and Barone's thoughts on the theory of costs and the supply curve. ${ }^{174}$ Pareto is also mentioned by Chamberlin for having distinguished 'between acting like a monopolist and acting like a competitor', and again for his contribution to the theory of duopoly. ${ }^{175}$ Sylos Labini cites Pantaleoni on the importance of fixed costs, ${ }^{176}$ while Stigler references Pareto for 'the possible effects of social controls over purchases and sales'. ${ }^{177}$ It is again to Pareto that Dennis attributes the abandonment of the idea of competition as activity; ${ }^{178}$ he also claims that Barone was one of the few economists 'to show much interest in Walras's work by the 1890s'. ${ }^{179}$ Backhouse recalls Pareto's innovations for Walras' theory of competition; ${ }^{180}$ Machovec calls Pareto's description of the behaviour of the

168 On De Viti de Marco's bibliography see Cardini (1995); on his contribution to the history of economic thought see Mosca (2005a).

169 An example of Barone's fame is found in Morgenstern's review of the German translation of his Principi in 1927; this edition contained an introduction by Schumpeter (1927), who also praised him in Capitalism, Socialism and Democracy, and in his essay on Pareto (Schumpeter 1942 and 1949). On Barone's contribution to the theory of marginal productivity see Baldin, Legris and Ragni (2012).

170 See Lombardini (1953, pp. 25-28, 53-54 for Pareto, and pp. 54-55 for Pantaleoni).

171 Schumpeter ([1954] 1976, pp. 972-973 and pp. 981-982).

172 Schumpeter (1949, p. 157).

173 Schumpeter ([1954] 1976, p. 857).

174 Schumpeter ([1954] 1976, p. 994).

175 Chamberlin ([1933] 1956, p. 16, pp. 36-37, p. 40, p. 52, pp. 222-223).

176 Sylos Labini ([1957] 1962, p. 89; 1995, pp. 197-199). Meacci (1998a, p. 3) emphasises the link between Pantaleoni and Sraffa. Bini (1995, section 5) deals with 'Competition, Firms and Entrepreneurs in the Economics of Maffeo Pantaleoni'.

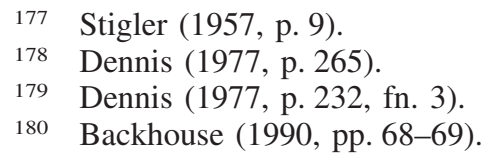


monopolist 'classical';181 and Blaug attributed to him the 'definition of the beneficial effects of competition' ${ }^{182}$ To this list of contributions, we can add others found in specific articles by individual economists: De Viti de Marco's article (1890a) on the telephone industry;183 Barone's insights on the development of U-shaped cost curves, ${ }^{184}$ the concept of natural monopoly, ${ }^{185}$ and the theory of competition; ${ }^{186}$ Pantaleoni's adherence to Spencer's evolutionism ${ }^{187}$ and his interest in coalitions. ${ }^{188}$ As can be seen, our economists' contributions seem very promising; however, no scholar has yet dealt with the specific subject of monopoly power in their thought.

\subsubsection{The international diffusion of their ideas}

Another important reason why these four Italian marginalists were chosen is that they were leading figures on the international scene, placing Italy at the centre of contemporary debates on economic theory and practice. For personal reasons, they were cosmopolitan, ${ }^{189}$ and this certainly helped them find a place in the cultural cross-fertilisation of the period. They engaged in correspondence with economists throughout the world, and their work was reviewed in the best journals, in which they in turn published articles and reviews; their textbooks were translated into various languages. ${ }^{190}$ The secondary literature confirms that Italian ideas made up a conspicuous proportion of those circulating among the

181 Machovec (1995, p. 183). He also mentions Barone: radically critical towards the perfectly competitive model, he assigns Barone the role of having 'encouraged the appealing ahistorical notion, directly rooted in Walras, that the basis of ownership was irrelevant to the achievement of static efficiency' (p. 75).

182 Baug (2001b, p. 43).

183 See Petretto (2014) and Mosca (2007a).

184 Keppler and Lallement (2006).

185 Mosca (2008).

186 Ragni (2012) and Mosca and Bradley (2013).

187 Mosca (2015a), Sunna and Mosca (2017).

188 Dardi (2014).

189 Pareto, born in Paris of a French mother, was nephew to an ambassador to Constantinople, and had one Russian and one French wife; Pantaleoni, whose mother was Irish, gained his qualifications from school in Germany; De Viti de Marco, whose grandmother was English, married an American woman; Barone had very close links with German culture.

190 Pantaleoni's textbook of 1889 was translated into English in 1898, De Viti de Marco's of 1928 was translated into German in 1932, into Spanish in 1934, and into English in 1936. Pareto's 1906 Manuale was translated into French in 1909 (but then translated into English only in 1971); Barone's Principi (1908) was translated into German in 1927 and into Spanish in 1942. 
economists of the marginalist age; ${ }^{191}$ there are therefore good reasons for asking ourselves if their thinking gained currency on the specific subject of monopoly power.

We shall also be evaluating their influence at the international level on the economic thought of the generations that followed them, and the outlook is promising because there is already some encouraging evidence available. The first regards Knight, mentioned previously for his exposition of the theory of perfect competition, who would appear to owe his 'rigorous notion of equilibrium' precisely to Pareto and Barone. ${ }^{192}$ Further evidence concerns the influence of Pantaleoni's theory of fixed costs on J.M. Clark ${ }^{193}$ and, through him, on the following theories of competition. De Viti de Marco inspired entire areas of research, ${ }^{194}$ and there is evidence of derivations from his ideas on the subjects of monopolistic power and the regulation of public utilities. ${ }^{195}$ There is also a thread that from Pareto leads to Lerner, via Amoroso, and to Lerner's famous index to measure market power, even though there is no proof of direct influence. ${ }^{196}$

\subsection{CONCLUSIONS}

This chapter has shown that there is a gap in the secondary literature regarding economic thinking on the sources of monopoly power before the 1930s. We have looked at the literature on the history of different topics (models of profit maximisation in non-competitive markets, antitrust, competition and industrial organisation) to find out which kind of limitation to entry economists before Bain (1956) took into account, the role these economists attributed to the number of firms present in the market, and their ideas on potential competition. The economists offering

\footnotetext{
191 On the diffusion of Italian thought see Asso (2001) and Asso and Fiorito (2001a and 2001b).

192 Marchionatti (2003, p. 66).

193 Sylos Labini ([1995] 1997, p. 197) states that Pantaleoni was followed by J.M. Clark (1923) on the question of overhead costs.

194 Buchanan (2003, p. 283) recognised the importance of De Viti de Marco as 'entry point' in the research project that led him to the Nobel Prize.

195 Petretto (2014) does not trace the actual paths of the ideas; but offers useful hints on how to look for them.

196 Keppler (1994b, p. 597) attributes to Amoroso, a follower of Pareto, the formulation in 1930 of an index similar to the one developed by Lerner four years later. Amoroso's priority is dealt with in depth and contextualised by Giocoli (2012).
} 
a promise under the terms of our enquiry were found to be from the Italian marginalist school of economic thought: Vilfredo Pareto, Maffeo Pantaleoni, Antonio de Viti de Marco and Enrico Barone. Having outlined the achievements and influence of the quartet, the next chapter addresses in more detail their theory and their vision of competition. 